\title{
THE RULE OF LAW AND THE IMPORTANCE OF PROCEDURE
}

\author{
JEREMY WALDRON
}

\section{Getting to the Rule of Law}

The Rule of Law is one star in a constellation of ideals that dominate our political morality: the others are democracy, human rights, and economic freedom. We want societies to be democratic; we want them to respect human rights; we want them to organize their economies around free markets and private property to the extent that this can be done without seriously compromising social justice; and we want them to be governed in accordance with the Rule of Law. We want the Rule of Law for new societies-for newly emerging democracies, for example-and old societies alike, for national political communities and regional and international governance, and we want it to extend into all aspects of governments' dealings with those subject to them-not just in day-to-day criminal law, or commercial law, or administrative law but also in law administered at the margins, in antiterrorism law and in the exercise of power over those who are marginalized, those who can safely be dismissed as outsiders, and those we are tempted just to destroy as (in John Locke's words) "wild Savage Beasts, with whom men can have no Society or Security." Getting to the Rule of Law does not just mean paying lip service to the ideal in the ordinary security of a prosperous modern democracy; it means extending the Rule of Law into societies that are not necessarily familiar with it; and 
in those societies that are familiar with it, it means extending the Rule of Law into these darker corners of governance, as well.

When I pay attention to the calls that are made for the Rule of Law around the world, I am struck by the fact that the features that people call attention to are not necessarily the features that legal philosophers have emphasized in their academic conceptions. Legal philosophers tend to emphasize formal elements of the Rule of Law, such as rule by general norms rather than particular decrees; rule by laws laid down in advance rather than by retrospective enactments; rule under a system of norms that has sufficient stability (is sufficiently resistant to change) so as to furnish for those subject to the norms a calculable basis for running their lives or their businesses; rules by norms that are made public, not hidden away in the closets of bureaucracy; rule by clear and determinate legal norms, norms whose meaning is not so obscure or contestable as to leave those who are subject to them at the mercy of official discretion. These are formal aspects of the Rule of Law, because they concern the form of the norms that are applied to our conduct: generality, prospectivity, stability, publicity, clarity, and so on. But we don't value them just for formalistic reasons. In F. A. Hayek's theory of the Rule of Law, we value these features for the contribution they make to predictability, which Hayek thinks is indispensable for liberty. ${ }^{2}$ In Lon Fuller's theory, we value them also for the way they respect human dignity: "To judge [people's] actions by unpublished or retrospective laws ... is to convey to [them] your indifference to [their] powers of self-determination." (I shall say more about this in section 5.) In Fuller's theory, too, there is a hunch that if we respect dignity in these formal ways, we will find ourselves more inhibited against more substantive assaults on dignity and justice. That has proved very controversial, but it is further evidence of the point that the interests of those who adopt a formal conception of the Rule of Law are not just formalistic.

I have said that this formal conception is not what ordinary people have in the forefront of their minds when they clamor for the extension of the Rule of Law into settings or modes of governance where it has not been present before. Saying that is usually a prelude to a call for a more substantive vision of the Rule of Law. I am not as hostile as I once was to a substantive conception of this ideal. ${ }^{4} \mathrm{I}$ believe that there is a natural overlap between 
substantive and formal elements, not least because-as we have just seen-the formal elements are usually argued for on substantive grounds of dignity and liberty. I still believe that it is important not to let our enthusiasm for a substantive conception-whereby the Rule of Law is treated as an ideal that calls directly for an end to human rights abuses or as an ideal that calls directly for free markets and respect for private property rights-obscure the independent importance that the formal elements I have mentioned would have even if these other considerations were not so directly at stake. ${ }^{5}$ But it is probably a mistake to exaggerate the distinctiveness of our several political ideals or the clarity of the boundaries between them.

Still, it is not a substantive conception that I have in mind when I say that ordinary people are urging something other than the formal elements that I have mentioned when they clamor for the Rule of Law. Instead, I have in mind elements of legal procedure and the institutions, like courts, that embody them. When people clamored recently in Pakistan for a restoration of the Rule of Law, their concern was for the independence of the judiciary and the attempt by an unelected administration to fire a whole slew of judges. ${ }^{6}$ When people clamor for the Rule of Law in China, they are demanding impartial tribunals that can adjudicate their claims. And when advocates for the detainees in the American base at Guantanamo Bay clamor for the Rule of Law, they are clamoring for hearings on their clients' comprehensive loss of liberty in which they or their clients would have an opportunity to put their case, confront and examine the evidence against them, such as it is, and make arguments for their freedom, in accordance with what we would say were normal legal procedures. ${ }^{7}$

\section{LAUNDRY LISTS}

What sort of procedural principles do I have in mind? Theorists of the Rule of Law are fond of producing laundry lists of demands. The best known are the eight formal principles of Lon Fuller's "inner morality of law": 8

1. Generality;

2. Publicity; 

3. Prospectivity;
4. Intelligibility;
5. Consistency;
6. Practicability;
7. Stability; and
8. Congruence.

I think we need to match this list with a list of procedural characteristics that are equally indispensable. As a preliminary sketch, ${ }^{9}$ we might say that no one should have any penalty, stigma, or serious loss imposed upon him by government except as the upshot of procedures that involve:

A. A hearing by an impartial tribunal that is required to act on the basis of evidence and argument presented formally before it in relation to legal norms that govern the imposition of penalty, stigma, loss, and so forth;

B. A legally trained judicial officer, whose independence of other agencies of government is ensured;

C. A right to representation by counsel and to the time and opportunity required to prepare a case;

D. A right to be present at all critical stages of the proceeding;

E. A right to confront witnesses against the detainee;

F. A right to an assurance that the evidence presented by the government has been gathered in a properly supervised way;

G. A right to present evidence in one's own behalf;

$\mathrm{H}$. A right to make legal argument about the bearing of the evidence and about the bearing of the various legal norms relevant to the case;

I. A right to hear reasons from the tribunal when it reaches its decision that are responsive to the evidence and arguments presented before it; and

J. Some right of appeal to a higher tribunal of a similar character.

These requirements are often associated with terms such as "natural justice," 10 and as such they are important parts of the Rule of Law. I believe we radically sell short the idea of the Rule of Law if 
we understand it to comprise a list like Fuller's list (1)-(8) without also including something like the procedural list $(\mathrm{A})-(\mathrm{J})$ that I have just set out. We say the Rule of Law is violated when due attention is not paid to these procedural matters or when the institutions that are supposed to embody these procedures are undermined or interfered with. Equally, I think we misrepresent the debate about whether the Rule of Law has also a substantive dimension if we do not contrast a possible list of substantive items - such as:

(a) Respect for private property;

( $\beta$ ) Prohibitions on torture and brutality;

( $\gamma$ ) A presumption of liberty; and

$(\delta)$ Democratic enfranchisement

-with both of the lists I have set out (the formal list and the procedural list), rather than with the formal list by itself.

\section{Form and Procedure in the Work of Hayek, Fuller, and Dicey}

It is remarkable how little attention is paid to demands of this procedural kind-demands like $(\mathrm{A})-(\mathrm{J})$ - in the literature in academic legal and political philosophy devoted specifically to discussion of the Rule of Law.

The key chapter in F. A. Hayek's book, The Constitution of Liberty-the chapter titled "Laws, Commands, and Order"-makes no mention whatever of courts or legal procedures; it is wholly concerned with the relation between formal characteristics like abstraction and generality and individual freedom..$^{11}$ Later chapters in that book do talk a little about courts but hardly ever about their procedures. ${ }^{12}$ The same is true of Hayek's later work on the Rule of Law, in his trilogy Law, Legislation and Liberty. Hayek talks a lot about the role of judges in chapter 5 of the first volume of that work. But it is all about the role of judges in generating norms of the appropriate form, rather than about the procedures that characterize courtrooms. ${ }^{13}$

The case of Lon Fuller is even more instructive. Fuller calls his internal morality of law-comprising (1) generality, (2) publicity, 
(3) prospectivity, and so on- "procedural," but what he seems to mean is that it is not substantive. Fuller says this:

As a convenient (though not wholly satisfactory) way of describing the distinction ... we may speak of a procedural, as distinguished from a substantive natural law. What I have called the internal morality of law is in this sense a procedural version of natural law, though to avoid misunderstanding the word "procedural" should be assigned a special and expanded sense so that it would include, for example, a substantive accord between official action and enacted law. The term "procedural" is, however, broadly appropriate as indicating that we are concerned, not with the substantive aims of legal rules, but with the ways in which a system of rules for governing human conduct must be constructed and administered if it is to be efficacious and at the same time remain what it purports to be. ${ }^{14}$

In fact, substantive can be contrasted either with procedural or with formal; the two contrasts are quite different, and patently what Fuller has in mind is what we should call a formal/substantive contrast. ${ }^{15}$ The features of his internal morality of law all relate to the form that legal norms take, not to either the procedure of their enactment or (more important) the procedural mode of their administration. Among his eight desiderata, only one comes close to being procedural (in the sense I am distinguishing from formal), namely the requirement of congruence between official action and law on the books-yet that is the one for which he says (in the passage quoted) "the word 'procedural' should be assigned a special and expanded sense"!

The point is that there is very little about due process or courtroom procedure in Fuller's account of law's internal morality in chapters 2 and 3 of The Morality of Law. ${ }^{16}$ Much the same is true of Fuller in his earlier response to H. L. A. Hart's Holmes Lecture. ${ }^{17}$ There, too, Fuller focuses on what we should call formal characteristics of law-generality, publicity, consistency, and so on-and his argument that they are prophylactics against injustice is based on an incompatibility between evil ends and law's forms.

$[\mathrm{C}]$ oherence and goodness have more affinity than coherence and evil. Accepting this belief, I also believe that when men are compelled to explain and justify their decisions, the effect will generally 
be to pull those decisions toward goodness, by whatever standards of ultimate goodness there are. ... [E]ven in the most perverted regimes there is a certain hesitancy about writing cruelties, intolerances, and inhumanities into law. ${ }^{18}$

The whole of his discussion along these lines, and the whole of his excoriation of Nazi "legality," has to do with legislative form, not judicial procedure. That is the ground on which Fuller makes what we would call his "Rule of Law" argument.

I do not mean that Fuller was uninterested in procedure. Towards the end of chapter 4 of The Morality of Law, there is some consideration about whether the internal morality of law applies to the processes by which allocative decisions are made by government agencies in a mixed economy. Fuller says we face problems of institutional design "unprecedented in scope and importance."

It is inevitable that the legal profession will play a large role in solving these problems. The great danger is that we will unthinkingly carry over to new conditions traditional institutions and procedures that have already demonstrated their faults of design. As lawyers we have a natural inclination to "judicialize" every function of government. Adjudication is a process with which we are familiar and which enables us to show to advantage our special talents. Yet we must face the plain truth that adjudication is an ineffective instrument for economic management and for governmental participation in the allocation of economic resources. ${ }^{19}$

This seems to indicate an interest in procedural as well as formal aspects of the Rule of Law (and, indeed, a skepticism about their . applicability across the board of all government functions).$^{20}$ But it is remarkable that the interest in the adjudicative process shown in this passage is not matched by anything in the earlier discussion in his book of the inner morality of law.

Fuller was in fact a great proceduralist, who made an immense contribution to our understanding of the judicial process. ${ }^{21}$ Nicola Lacey has ventured the suggestion that Fuller would have been on much stronger ground in his argument with Hart had he focused on procedural and institutional as well as formal aspects of legality. ${ }^{22}$ But he allowed Hart to set the agenda, with the crucial question "What is law and what is its relation to morality?" and did not force him to open that up, in any particular way, to "What, in 
terms of institutional procedures, is a legal system, and what is the relation of all that to morality?"

Fortunately, we are not bound to follow him in that. I think we can usefully pursue a procedural (and institutional) dimension of the Rule of Law, as well as a formal dimension, and distinguish both of them (separately as well as jointly) from a more substantive conception. There is certainly precedent for this elsewhere in the Rule of Law literature.

Albert Venn Dicey, for example, when he explained the Rule of Law as a distinguishing feature of the English Constitution, identified it in the first instance with the following feature:

When we say that the supremacy or the rule of law is a characteristic of the English constitution, we ... mean, in the first place, that no man is punishable or can be lawfully made to suffer in body or goods except for a distinct breach of law established in the ordinary legal manner before the ordinary Courts of the land. In this sense the rule of law is contrasted with every system of government based on the exercise by persons in authority of wide, arbitrary, or discretionary powers of constraint. ${ }^{23}$

The passage I have emphasized is important. Without it, we tend to read the contrast between the rule of law and arbitrary government in terms of the application of a rule versus purely individualized application of punishment (without guidance by a rule). With it, however, the contrast between law and discretion has to do with institutions and procedures: a person must not be made to suffer except pursuant to a decision of a court arrived at in the ordinary manner observing ordinary legal process.

When E. P. Thompson insisted (alarming his fellow Marxists) that the Rule of Law was "an unqualified human good" and a "cultural achievement of universal significance," ${ }^{24}$ he did so by reference in large part to the importance of procedure:

$[\mathrm{N}]$ ot only were the rulers (indeed, the ruling class as a whole) inhibited by their own rules of law against the exercise of direct unmediated force (arbitrary imprisonment, the employment of troops against the crowd, torture, and those other conveniences of power with which we are all conversant), but they also believed enough in these rules, and in their accompanying ideological rhetoric, to allow, in certain limited areas, the law itself to be a genuine forum 
within which certain kinds of class conflict were fought out. There were even occasions . . . when the Government itself retired from the courts defeated. ${ }^{25}$

As I said earlier, in recent legal philosophy the phrase "the Rule of Law" is often used to conjure up a sort of laundry list of features that a healthy legal system should have. These are mostly variations of the eight formal desiderata of Lon Fuller's "internal morality," 26 but occasionally procedural and institutional considerations creep in. Thus, the fourth, fifth, and seventh items on Joseph Raz's list are the following: "(4) The independence of the judiciary must be guaranteed ... (5) The principles of natural justice must be observed ... [o]pen and fair hearing, absence of bias, and the like ... (7) The courts should be easily accessible." 27 The justifications Raz gives often go to the issue of legal determinacy (e.g., "Since the court's judgment establishes conclusively what is the law in the case before it, the litigants can be guided by law only if the judges apply the law correctly"), but at least the procedural and institutional considerations rate a mention.

In many other discussions of the Rule of Law, however, the procedural dimension is simply ignored (or, worse, it is assumed thoughtlessly that the procedural dimension is taken care of by calling the formal dimension "procedural"). I do not mean that judges and courts are ignored. In the last Nomos volume devoted to this subject, there is extensive discussion of judicial authority and judicial discretion: some of it is about equitable decision by judges in hard cases (together with an intriguing account of the idea of practical wisdom as applied to the judiciary), and some of it is about the interpretive techniques that judges should use in difficult cases. ${ }^{28}$ But, if one didn't know better, one would infer from these discussions that problems were just brought to wise individuals called judges for their decision (with or without the help of sources of law) and that the judges in question proceeded to deploy their interpretive strategies and practical wisdom to address those problems; there is no discussion in these papers of the highly proceduralized hearings in which problems are presented to a court, let alone the importance of the various procedural rights and powers possessed by individual litigants in relation to these hearings. Certainly, there is no indication by any of 
the volumes' contributors that the procedures themselves and the rights and powers associated with them are in and of themselves part of what we value under the heading of "the Rule of Law."

\section{Procedure and the Concept of Law}

Elsewhere I have remarked on an interesting parallel between the failure of some of our leading theorists of the Rule of Law to highlight procedural (as opposed to formal) considerations and the failure of our leading legal philosophers to include procedural and institutional elements in their conception of law itself. ${ }^{29}$

For my part, I do not think we should regard something as a legal system absent the existence and operation of the sort of institutions we call courts. By courts, I mean institutions that apply norms and directives established in the name of the whole society to individual cases and that settle disputes about the application of those norms. And I mean institutions that do this through the medium of hearings, formal events that are tightly structured procedurally in order to enable an impartial body to determine the rights and responsibilities of particular persons fairly and effectively after hearing evidence and argument from both sides. ${ }^{30}$

It is remarkable how little there is about courts in the conceptual accounts of law presented in modern positivist jurisprudence. The leading source is H. L. A. Hart's magisterial work, The Concept of Law. Hart conceives of law in terms of the union of primary rules of conduct and secondary rules that govern the way in which the primary rules are made, changed, applied, and enforced. He certainly seems to regard something like courts as essential. When he introduces the concept of secondary rules, he talks of the emergence of "rules of adjudication" in the transition from a pre-legal to a legal society: "secondary rules empowering individuals to make authoritative determinations of the question of whether, on a particular occasion, a primary rule has been broken." ${ }^{31}$ Notice, however, that this account defines the relevant institutions simply in terms of their output function-the making of "authoritative determinations ... of whether ... a primary rule has been broken." There is nothing on the distinctive process by which this function is performed. ${ }^{32}$ A Star Chamber proceeding ex parte without any sort of hearing would satisfy Hart's definition; 
and so would the tribunals we call in the antipodes "kangaroo courts."

Much the same is true of Joseph Raz's view about the importance of what he calls primary norm-applying institutions in Practical Reason and Norms and elsewhere. ${ }^{33}$ Raz believes that normapplying institutions are key to our understanding of legal systems (much more so than legislatures).$^{34}$ Now, there are all sorts of institutionalized ways in which norms may be applied, according to Raz, but "primary norm-applying organs" are of particular interest. Raz describes their operation as follows: "They are institutions with power to determine the normative situation of specified individuals, which are required to exercise these powers by applying existing norms, but whose decisions are binding even when wrong." 35 He tells us that "[c]ourts, tribunals and other judicial bodies are the most important example of primary organs." ${ }^{36}$ In his abstract philosophical account, however, the operation of primary normapplying institutions is understood solely in terms of output (and in terms of what is done with their output). Again, there is nothing about mode of operation or procedure. Secret military commissions might meet to "determine the normative situation of specified individuals . . . by applying existing norms" in the absence of the individuals in question and without affording any sort of hearing. The impression one gets from Raz's account is that a system of rule dominated by institutions like that would count as a legal system. Of course, Raz would criticize such institutions, and, as we have seen, he might use the ideal of the Rule of Law to do so. ${ }^{37} \mathrm{But}$ he seems to suggest that this is relevant to law only at an evaluative level, not at the conceptual level.

I think there is a considerable divergence here between what these philosophers say about the concept of law and how the term is ordinarily used. Most people, I think, would regard hearings and impartial proceedings and the safeguards that go with them as an essential, rather than a contingent, feature of the institutional arrangements we call legal systems. ${ }^{38}$ Their absence would for most people be a disqualifying factor, just like the absence of free and fair elections in what was alleged to be a democracy.

Moreover, a procedural conception of the Rule of Law helps bring our conceptual thinking about law to life. There is a distressing tendency among academic legal philosophers to see law simply 
as a set of normative propositions and to pursue their task of developing an understanding of the concept of law to consist simply in understanding what sort of normative propositions these are. But law comes to life in institutions. An understanding of legal systems that emphasizes argument in the courtroom as much as the existence and recognition of rules provides the basis for a much richer understanding of the values and requirements that law and legality represent in modern political argument.

If it were up to me, I would bring the two concepts togetherthe concept of law and the concept of legality or the Rule of Law. I would suggest that the concept of law should be understood along Fullerian lines to embrace the fundamental elements of legality, but I would argue this only if the latter were understood to give pride of place to procedural and institutional elements. You may be relieved to hear that that is not the task of the present essay. However, I have attempted this elsewhere and so have one or two others. ${ }^{39}$ But it is not the received position. According to Joseph Raz and others, you cannot understand what the Rule of Law is unless you already and independently understand what law is and the characteristic evils law is likely to give rise to. ${ }^{40} \mathrm{I}$ mention this further conceptual debate in order to register the points that the absence of a proper emphasis on procedural aspects on either side -in the academic account of the concept of law and in the academic account of the Rule of Law-may have a common source and may have something to do with our inability to see the connection between the two ideas.

\section{Procedure and the Underlying Moral Concerns}

When Fuller developed his formal principles of generality, prospectivity, clarity, stability, consistency-principles whose observance is bound up with the basics of legal craftsmanship ${ }^{41}$ - legal positivists expressed bewilderment as to why he called this set of principles a "morality." ${ }^{2} \mathrm{He}$ did so because he thought his eight principles had inherent moral significance. It was not only that he believed that observing them made it much more difficult to do substantive injustice, though this he did believe. ${ }^{43}$ It was also because he thought observing the principles he identified was itself a way of respecting human dignity: 
To embark on the enterprise of subjecting human conduct to rules involves ... a commitment to the view that man is ... a responsible agent, capable of understanding and following rules. ... Every departure from the principles of law's inner morality is an affront to man's dignity as a responsible agent. To judge his actions by unpublished or retrospective laws, or to order him to do an act that is impossible, is to convey . . your indifference to his powers of self-determination. ${ }^{44}$

I think what Fuller said about the connection between his formal principles and dignity can be said even more about the connection between procedure and dignity.

The essential idea of procedure is much more than merely functional: applying norms to individual cases. It is partly structural; it involves Martin Shapiro's idea of the triad structure: ${ }^{45}$ a first party, a second opposing party, and, above them, a separate, impartial officer with the authority to make a determination. Most important, it is procedural: the operation of a court involves a way of proceeding that offers those who are immediately concerned in the dispute or in the application of the norm an opportunity to make submissions and present evidence (such evidence being presented in an orderly fashion according to strict rules of relevance oriented to the norms whose application is in question). The mode of presentation may vary, but the existence of such an opportunity does not. Once presented, the evidence is made available to be examined and confronted by the other party in open court. And each party has the opportunity to present arguments and submissions at the end of this process and to answer those of the other party. In the course of all of this, both sides are treated respectfully, if formalistically, but, above all, they are listened to by a tribunal that (as Lon Fuller stressed in his work "Forms and Limits of Adjudication") is bound in some manner to attend to the evidence presented and to respond to the submissions that are made in the reasons it eventually gives for its decision. ${ }^{46}$

These are abstract characteristics, and, of course (as I said), it would be a mistake to try to get too concrete given the variety of court-like institutions in the world. But they are not just arbitrary abstractions. They capture a deep and important sense associated foundationally with the idea of a legal system, that law is a mode of governing people that treats them with respect, as though they 
had a view or perspective of their own to present on the application of the norm to their conduct and situation. Applying a norm to a human individual is not like deciding what to do about a rabid animal or a dilapidated house. It involves paying attention to a point of view and respecting the personality of the entity one is dealing with. As such, it embodies a crucial dignitarian idea-respecting the dignity of those to whom the norms are applied as beings capable of explaining themselves. None of this is present in the dominant positivist account; all of it, I submit, should be regarded as an essential aspect of our working conception of law.

\section{Apprehensions about Lawlessness}

Think of the concerns expressed about the plight of detainees in Guantanamo Bay from 2003 to the present. When jurists worried that the detention facility there was a "black hole" so far as legality was concerned, ${ }^{47}$ it was precisely the lack of these procedural rights that they were concerned about. What the detainees demanded, in the name of the Rule of Law, was an opportunity to appear before a proper legal tribunal, to confront and answer the evidence against them (such as it was), and to be represented so that their own side of the story concerning their detention could be explained to a tribunal that (as I said) would be required to listen and respond to the arguments that were made. That was the gist of their habeas corpus demands. No doubt the integrity of these proceedings would depend in part on the formal characteristics of the legal norms (whether laws and customs of armed conflict or other antiterrorist laws) that were supposed to govern their detention, whose application in their case they could call in question at the hearings that they demanded; no doubt the formal features stressed by Fuller, Hayek, and others would be important, because it is very difficult to make a case at a hearing if the laws governing detention are unacceptably vague, or indeterminate, or kept secret. Even so, we still miss out on a whole important dimension of the Rule of Law ideal if we do not also focus on the procedural demands themselves, which, as it were, give the formal side of the Rule of Law this purchase. ${ }^{48}$

These concerns are prominent not just in extreme cases like Guantanamo Bay. Among working lawyers, they have been at the 
forefront of concerns about the compatibility of the Rule of Law with the modern administrative state. When Dicey spoke of a "Decline in Reverence for the Rule of Law" in England at the beginning of the twentieth century, one of the things he had in mind was the transfer of authority to impose penalties or take away property or livelihood from courts to administrative entities, and the content of his concern was precisely that those entities would not act as courts acted, would not feel constrained by rules of procedure and other scruples of "natural justice" in the way that judges characteristically felt constrained. ${ }^{49}$ True, even Dicey expressed this partly in terms of the existence of determinate rules:

State officials must more and more undertake to manage a mass of public business. ... But Courts are from the nature of things unsuited for the transaction of business. The primary duty of a judge is to act in accordance with the strict rules of law. He must shun, above all things, any injustice to individuals. The well-worn and often absurdly misapplied adage that "it is better that ten criminals should escape conviction than that one innocent man should without cause be found guilty of crime" does after all remind us that the first duty of a judge is not to punish crime but to punish it without doing injustice. A man of business, whether employed by a private firm or working in a public office, must make it his main object to see that the business in which he is concerned is efficiently carried out. He could not do this if tied down by the rules which rightly check the action of a judge..$^{50}$

I guess one could parse this purely in terms of judges (as opposed to managers of public business) being bound by determinate rules -and then the whole thing could be brought in under Fuller's eighth principle of congruence. ${ }^{51}$ But, again, I think that would miss a whole dimension of the matter. It is not simply that one bunch of officials are bound to apply determinate rules while another bunch of officials are not; it is that the former operate in the context of highly proceduralized institutions in which procedural rights and duties of all sorts are oriented to allowing the application of determinate rules to be established fairly and minutely with ample opportunity for contestation. If we neglect this aspect of the Rule of Law, we make much of Dicey's concern about contemporary decline in regard for that ideal quite mysterious.

Something similar may be true of our concerns about the role 
of the Rule of Law in nation building. When theorists like Robert Barro argue that it is more important to secure the Rule of Law in a developing society than it is to secure the institutions of democracy, what they often have in mind is the elimination of corruption and the establishment of stable legal institutions. ${ }^{52}$ We cannot understand these concerns unless we focus on the distinctive procedural features of legal institutions and their procedural integrity vis-à-vis the elimination of corruption, the securing of judicial independence, the guarantee of due process, and the separation of powers.

True, it has to be said also that sometimes when commentators call for the Rule of Law to be given priority over democracy in developing societies, what they mainly have in mind are quasisubstantive features like the protection of property, the proper enforcement of contracts, and the protection of outside investments, and the safeguarding of all this as against democratically enacted social-justice or environmental or labor-rights legislation. Sometimes this is quite cynical..$^{53} \mathrm{I}$ have argued vehemently elsewhere against this Washington-consensus-based abuse of the idea of the Rule of Law. ${ }^{54}$

\section{Law, Argumentation, and Predictability}

When I set out my preliminary list of procedural characteristics of the Rule of Law at the beginning of this chapter, I mentioned the requirement that those facing the imposition of penalty, stigma, or serious loss at the hands of government must have the right to make legal argument about the bearing of the evidence and about the bearing of the various legal norms relevant to the case. I believe this is particularly important. But it also sets up an interesting tension between the procedural requirements of the Rule of Law and the formal requirements that relate to the determinacy of legal norms.

In the systems with which we are familiar, law presents itself as something one can make sense of. The norms that are administered in our legal system may seem like just one damned command after another, but lawyers and judges try to see the law as a whole; they attempt to discern some sort of coherence or system, integrating particular items into a structure that makes intellectual sense. ${ }^{55}$ 
And ordinary people and their representatives take advantage of this aspiration to systematicity and integrity in framing their own legal arguments, by inviting the tribunal hearing their case to consider how the position they are putting forward fits generally into a coherent conception of the spirit of the law. These are not just arguments about what the law ought to be-made, as it were, in a sort of lobbying mode. They are arguments of reason that present competing arguments about what the law is. Inevitably, they are controversial: one party will say that such-and-such a proposition cannot be inferred from the law as it is; the other party will respond that it can be so inferred if only we credit the law with more coherence (or coherence among more of its elements) than people have tended to credit it with in the past. And so the determination of whether such a proposition has legal authority may often be a matter of contestation. Law, in other words, becomes a matter of argument. ${ }^{56}$

In this regard, too, law has a dignitarian aspect: it conceives of the people who live under it as bearers of reason and intelligence. They are thinkers who can grasp and grapple with the rationale of the way they are governed and relate it in complex but intelligible ways to their own view of the relation between their actions and purposes and the actions and purposes of the state. Once again, I don't think we would accept that a society was governed by the Rule of Law if its judicial procedures did not afford parties the opportunity to make arguments of this kind in complex cases where the state was bearing down on them.

But this strand of the Rule of Law, this strand of dignitarian respect, has a price: it probably brings with it a diminution in law's certainty. On my view, the procedural side of the Rule of Law requires that public institutions sponsor and facilitate reasoned argument in human affairs. But argument can be unsettling, and the procedures that we cherish often have the effect of undermining the certainty and predictability that are emphasized in the formal side of the ideal. ${ }^{57}$ By associating the Rule of Law with the legal process rather than with the form of the determinate norms that are supposed to emerge from that process, the procedural aspect of the Rule of Law seems to place a premium on values that are somewhat different from those emphasized in the formal picture. ${ }^{58}$ The formal picture, particularly as it is put forward by thinkers like 
F. A. Hayek, emphasizes clarity, determinacy, and predictability as features of governance that make private freedom possible. ${ }^{59}$ The procedural idea sponsors a certain conception of freedom also, but it is more like positive freedom: active engagement in the administration of public affairs, the freedom to participate actively and argumentatively in the way that one is governed. And that positive freedom may stand in some tension with private freedom in Hayek's vision of liberty, which presupposes that law is determinate enough to allow people to know in advance where they stand and to have some advance security in their understanding of the demands that law is likely to impose upon them.

The tension may also be represented as a tension between various strands of dignity associated with the Rule of Law. Fuller, we saw, associated his formal criteria with a dignitarian conception of the legal subject as an agent capable of monitoring and freely governing his own conduct. In its action-guiding aspect, law respects people as agents; the Rule of Law is sometimes represented as the conditions of such respect. ${ }^{60}$ But how, it may be asked, can we maintain this mode of respect if law becomes contestable and uncertain as a result of argumentation? Insisting on an opportunity for argumentation respects dignity, too, but at the cost of diminishing the confidence that we can have in the dignity of law's self-application at the hands of ordinary individuals. On the other hand, it is worth remembering that law consists not only of determinate rules but also standards and that law's confidence in the possibility of self-application does not necessarily presuppose that it takes the form only of determinate rigid rules. Law's dignitarian faith in the practical reason of ordinary people may be an act of faith in their thinking - for example, about what is reasonable and what is not-not just in their recognition of a rule and its mechanical application. And so also it may be an act of faith not just in their ability to apply general moral predicates (such as "reasonable") to their actions but also to think about and interpret the bearing of a whole array of norms and precedents to their conduct, rather than just the mechanical application of a single norm.

So we cannot just brush the argumentative aspect of law's procedures aside so far as the Rule of Law is concerned. I believe this tension in the Rule of Law ideal is largely unavoidable, and we should own up to the fact that the Rule of Law points, as it were, 
in both directions. I think we find symptoms of this tension in the ambivalence of the Rule of Law ideal so far as the role of judges in society is concerned and in a similar ambivalence about the role of litigation. ${ }^{61}$

There is no denying that theories that place great stress on legal certainty, predictability, and settlement, on the determinacy and intelligibility of the norms that are upheld in society, and on the relatively straightforward character of their administration by the state are among the most influential conceptions of the Rule of Law. ${ }^{62}$ According to these conceptions, the most important thing that people need from the law that governs them is certainty and predictability in the conduct of their lives and businesses. There may be no getting away from legal constraint in the circumstances of modern life, but freedom is possible nevertheless if people know in advance how the law will operate and how they have to act if they are to avoid its application. Knowing in advance how the law will operate enables one to make plans and to work around its requirements. ${ }^{63}$ And knowing that one can count on the law's protecting certain personal property rights gives each citizen some certainty on what he can rely on in his dealings with other people and the state. Accordingly, they highlight the role of rules rather than standards, literal meanings rather than systemic inferences, direct applications rather than arguments, and ex ante clarity rather than labored interpretations. ${ }^{64}$ The Rule of Law is violated, on this account, when the norms that are applied by officials do not correspond to the norms that have been made public to the citizens or when officials act on the basis of their own discretion rather than according to norms laid down in advance. If action of this sort becomes endemic, then not only are people's expectations disappointed, but increasingly they will find themselves unable to form expectations on which they can rely, and the horizons of their planning and their economic activity will shrink accordingly. So it is natural to think that the Rule of Law must condemn the uncertainty that arises out of law's argumentative character.

But the contrary considerations embodied in the procedural side of the Rule of Law will not easily give way. As the late and lamented Neil MacCormick has pointed out, law is an argumentative discipline, and no analytic theory of what law is and what distinguishes legal systems from other systems of governance can 
afford to ignore this aspect of our legal practice and the distinctive role it plays in a legal system's treating ordinary citizens with respect as active centers of intelligence ${ }^{65} \mathrm{~A}$ fallacy of modern positivism, it seems to me, is its exclusive emphasis on the commandand-control aspect of law, or the norm-and-guidance aspect of law, without any reference to the culture of argument that a legal system frames, sponsors, and institutionalizes. The institutionalized recognition of a distinctive set of norms may be an important feature. But at least as important is what we do in law with the norms that we identify. We don't just obey them or apply the sanctions that they ordain; we argue over them adversarially, we use our sense of what is at stake in their application to license a continual process of argument back and forth, and we engage in elaborate interpretive exercises about what it means to apply them faithfully as a system to the cases that come before us.

When positivists in the tradition of $\mathrm{H}$. L. A. Hart pay attention to this aspect of interpretation and argument, they tend to treat it as an occasional and problematic sideline. The impression given is that, in most cases, the authoritative identification of legal norms using a rule of recognition is sufficient; once it is recognized, a legal norm can become a straightforward guide to official action. But, it is said, occasionally the language is unclear-because words have open texture or because our aims are indeterminate or because for some other reasons there is a hiccough in the interface between words and the facts that they apply to-and then, unfortunately, we have no choice but to argue the matter through. ${ }^{66}$ And, usually, the positivist will add, the upshot is that the court will just have to cut through the Gordian knot and make a new rule that can be recognized and applied more readily without any attendant controversy. ${ }^{67}$ But this account radically underestimates the point that argumentation (about what this or that provision means or about the effect of this array of precedents) is business as usual in law. We would be uneasy about counting a system that did not exhibit it and make routine provision for it as a legal system.

So: I don't think that a conception of law or a conception of the Rule of Law that sidelines the importance of argumentation can really do justice to the value we place on government treating ordinary citizens with respect as active centers of intelligence. The demand for clarity and predictability is commonly made in 
the name of individual freedom-the freedom of the Hayekian individual in charge of his own destiny who needs to know where he stands so far as social order is concerned. ${ }^{68}$ But, with the best will in the world and the most determinate-seeming law, circumstances and interactions can be treacherous. From time to time, the free Hayekian individual will find himself charged or accused of some violation. Or his business will be subject-as he thinks, unjustly or irregularly - to some detrimental rule. Some such cases may be clear, but others may be matters of dispute. An individual who values his freedom enough to demand the sort of calculability that the Hayekian image of freedom under law is supposed to cater to is not someone whom we can imagine always tamely accepting a charge or a determination that he has done something wrong. He will have a point of view, and he will seek an opportunity to bring that to bear when it is a question of applying a rule to his case. And, when he brings his point of view to bear, we can imagine his plaintiff or his prosecutor responding with a point of view whose complexity and tendentiousness matches his own. And so it begins: legal argumentation and the facilities that law's procedures make for the formal airing of these arguments. ${ }^{69}$ Courts, hearings, and arguments-those aspects of law are not optional extras; they are integral parts of how law works, and they are indispensable to the package of law's respect for human agency. To say that we should value aspects of governance that promote the clarity and determinacy of rules for the sake of individual freedom but not the opportunities for argumentation that a free and self-possessed individual is likely to demand, is to slice in half, to truncate, what the Rule of Law rests upon: respect for the freedom and dignity of each person as an active intelligence.

\section{Legal Procedures in Social and Political Degision Making}

Alexis de Tocqueville famously remarked that "[s]carcely any political question arises in the United States that is not resolved, sooner or later, into a judicial question." ${ }^{70}$ Does a proceduralist account of the Rule of Law, with its emphasis on due process and the sort of argumentation that one finds in courtrooms, endorse this characteristic? Is a society governed by the Rule of Law necessarily a 
society in which judicial procedures loom large in the settlement of social and political questions?

I think that is, for the most part, an unwarranted extrapolation. It is one thing to say that a person threatened by the government with penalty, stigma, or serious loss must be offered an opportunity and a setting for argumentatively contesting that imposition. It is another thing to say that the courtroom setting, with its highly proceduralized modes of consideration, is an appropriate venue for settling general questions of common concern in a society. We may accept the procedural implications of the Rule of Law-along the lines of those set out in my list (A)- $(\mathrm{J})$ in section 2-without denying that, nevertheless, in the end, the legislature, rather than the courtroom, is the appropriate place for settling such matters. Certainly, what happens in the courtroom in argument about particular applications may affect how the measures enacted in the legislature are subsequently understood. That, as I have said, may have an effect on predictability, and we should not be in the business of trying to avoid that by minimizing the impact of judicial proceedings. Such an effect can and will accrue even in a society in which courts do not have the power to override legislation, and endorsing or accepting that effect by no means amounts to an endorsement of anything like judicial review of legislation.

I do not mean that the Rule of Law precludes judicial review of legislation. I believe that, as a political ideal, it is neutral on the issue. In a society with a constitutional Bill of Rights and a practice of strong judicial review, the Rule of Law requires us to accept a much greater role for courts in public decision making than I have set out here. In such a society-I am thinking particularly of the United States-arguments made in courtrooms according to the procedural principles that I say constitute the Rule of Law will have a greater impact on the life of a society and a greater impact probably on social predictability than they have in a society with weak or no judicial review. ${ }^{71}$ Also, the more robust the Bill of Rights, the more it will seem that the upshot of taking the Rule of Law seriously is substantive, not just procedural and formal. This, I think, is the gist of Dworkin's position on the Rule of Law in A Matter of Principle. ${ }^{72}$

Some people argue that the Rule of Law in a society is incomplete unless legislatures as much as executive agencies are bound 
to act in accordance with (higher) constraining laws. I do not accept that, though I understand the position. Some even say that the crucial distinction here is between the Rule of Law and rule by law, and they say that a system of legislative supremacy is an example of the latter but not the former. A position like this is sometimes associated with a general denigration of legislaturesas though, in the end, the Rule of Law must amount to something other than the rule of men. The position is often associated with an almost mythic reverence for common law, not conceived necessarily as deliberately crafted by judges but understood as welling up impersonally as a sort of resultant of the activity of courts. Hayek hints at some such nonsense when he writes in The Constitution of Liberty that most genuine rules of law

have never been deliberately invented but have grown through a gradual process of trial and error in which the experience of successive generations has helped to make them what they are. In most instances, therefore, nobody knows or has ever known all the reasons and considerations that have led to a rule being given a particular form. ${ }^{73}$

In a similar way, the suggestion that legislatures need to be constrained by law rather than regarded as ultimate sources of law often involves a strange sort of constitutionalist mythology. It sees the framing of a constitution or a Bill of Rights as some sort of transcendent event-amounting to something other than the rule of men (by law): perhaps it is supposed to have been a spontaneous effulgence of unprecedented superhuman virtue hovering around the activity of giants like James Madison and the Federalists. But I see no reason to associate the Rule of Law with any such mythology or to embody in it any denial that law is human in origin and often the product of deliberate manufacture. Even if positivists (as I have argued) give an inadequate account of it, the Rule of Law is, in the end, the rule of positive law; it is a human ideal for human institutions, not a magic that somehow absolves us from human rule.

Having said that, let me add two final points by way of qualification. First, even in systems of parliamentary supremacy, legislatures do act in ways that are constituted by rules, and procedural rules at that. (I mention this because, sometimes, when people allude to 
the procedural side of the Rule of Law, they have in mind the way laws are made, rather than-as I have emphasized-the way they are administered.) They are-in their own way-highly proceduralized institutions, and people rely on their articulated procedures as indicating the points of access at which citizens can hope to influence and participate in their proceedings. It is no accident that enemies of the Rule of Law, such as Carl Schmitt, sought comprehensively to disparage the rule-governed character of parliamentary democracy. ${ }^{74}$

Second, the Rule of Law applies not only within national polities but also increasingly between them. The Rule of Law as an international legal ideal remains undertheorized, ${ }^{75}$ and I am afraid much of the work that has been done on it simply adopts uncritically the perspective of those who say, at the national level, that the ideal consists in determinacy, clarity, and predictability. ${ }^{76} \mathrm{I}$ believe there is much more to be said on this. I have tried to say some of it in some other writings, ${ }^{77}$ and I will try to say more. For the moment, this must suffice: to the extent that we take international law seriously, it will be the case that national legislatures, like other national institutions, will appropriately regard themselves as bound and constrained by law in what they do (whether or not they have a national Bill of Rights). The content of that constraint will be determined by the content of multilateral treaties (including human rights conventions), by customary international law, and by ius cogens provisions of various kinds. The character of the constraint will no doubt be determined, formally and procedurally (if not substantively), by the ideal of the Rule of Law, adapted to the international context. Accordingly, it is a matter of some urgency -which more or less implies these days that legal philosophers are going to neglect it-to consider what that adaptation of this ideal to the international context involves.

\section{NOTES}

1. John Locke, Two Treatises of Government (Cambridge: Cambridge University Press, 1988), 274 (II: section 11).

2. F. A. Hayek, The Constitution of Liberty (Chicago: University of Chicago Press, 1960), esp. chs. 9-10. 
3. Lon L. Fuller, The Morality of Law (New Haven: Yale University Press, 1969), 162.

4. See Jeremy Waldron, "The Rule of Law in Contemporary Liberal Theory," Ratio Juris 2 (1989): 79. For a discussion of substantive Rule of Law ideas, see Paul Craig, "Formal and Substantive Conceptions of the Rule of Law: An Analytical Framework," Public Law (1997): 467.

5. See Jeremy Waldron, "Legislation and the Rule of Law," Legisprudence 1 (2007): 91, 115.

6. See, e.g., Editorial, "Gathering Storm," New York Times, November 8, 2007: "The American Bar Association, its members horrified by events in Pakistan, has written to General Musharraf and condemned his profound breach of the rule of law." See also Letter, "Pakistan's Leaders Must Respect the Rule of Law," The Times (London), November 14, 2007 (signed by chairs of Bar Associations in England, Scotland, Ireland, and Wales).

7. See, e.g., Editorial, "The Rule of Law in Guantánamo," New York Times, October 11, 2008, and Laura Dickinson, "Using Legal Process to Fight Terrorism: Detentions, Military Commissions, International Tribunals, and the Rule of Law," Southern California Law Review 75 (2002): 1407.

8. See also the lists in John Finnis, Natural Law and Natural Rights (Oxford: Clarendon Press, 1980), 270; John Rawls, A Theory of Justice (Cambridge, MA: Harvard University Press, 1971), 236-39; and Joseph Raz, "The Rule of Law and Its Virtue," in his collection The Authority of Law: Essays on Law and Morality (Oxford: Clarendon Press, 1979), 214-19.

9. I have adapted this list from A. Wallace Tashima, "The War on Terror and the Rule of Law," Asian American Law Journal 15 (2008): 245, 264.

10. In the United Kingdom and elsewhere, the term "natural justice" is used to refer to the most elementary aspects of what Americans would call procedural due process. See, for example, Paul Jackson, Natural Justice (London: Sweet and Maxwell, 1979).

11. Hayek, Constitution of Liberty, 148-61.

12. See ibid., 218-19, for the suggestion that, apart from the formal characteristics of the Rule of Law, its procedural aspects are unimportant: "[T] hey presuppose for their effectiveness the acceptance of the rule of law as here defined and ..., without it, all procedural safeguards would be valueless."

13. F. A. Hayek, Rules and Order, vol. 1 of Law, Legislation and Liberty (Chicago: University of Chicago Press, 1973), 94-123.

14. Fuller, Morality of Law, 96-97.

15. Brian Tamanaha, On the Rule of Law: History, Politics, Theory (New York: Cambridge University Press, 2004), gets this right by locating his discussion of Fuller in a chapter called "Formal Theories." That is then contrasted with a chapter called "Substantive Theories." Procedural theories 
don't rate a mention, but at least it is not assumed by Tamanaha that everything nonsubstantive is procedural.

16. There is a reference to "due process" in Fuller, Morality of Law, 1056 , but that is in the technical sense of the term, and it addresses whether ex post facto laws violate due process (in that sense).

17. Lon L. Fuller, "Positivism and Fidelity to Law: A Reply to Hart," Harvard Law Review 71 (1959): 630.

18. Ibid., 636-37.

19. Fuller, Morality of Law, 176.

20. For the implications of this for Fuller's theory, see Jeremy Waldron, "The Appeal of Law: Efficacy, Freedom, or Fidelity," in Law and Philosophy 13 (1994): 259, 272-75.

21. See Lon L. Fuller, "The Forms and Limits of Adjudication," Harvard Law Review 92 (1978): 353.

22. See Nicola Lacey, "Out of the 'Witches' Cauldron?-Reinterpreting the Context and Re-assessing the Significance of the Hart-Fuller Debate," in The Hart-Fuller Debate in the Twenty-First Century, ed. Peter Cane (Oxford: Hart, 2010), 1.

23. A. V. Dicey, Introduction to the Study of the Law of the Constitution, 8th ed. (Indianapolis: Liberty Classics, 1982), 110 (my emphasis).

24. E. P. Thompson, Whigs and Hunters: The Origin of the Black Act (Harmondsworth: Penguin Books, 1977), 265-66.

25. Ibid., 265.

26. See, e.g., Finnis, Natural Law and Natural Rights, 270.

27. Raz, "The Rule of Law and Its Virtue," 216-17.

28. See the essays on equitable judgment and practical reason by Lawrence Solum, "Equity and the Rule of Law," in Nomos XXXVI: The Rule of Law, ed. Ian Shapiro (New York: New York University Press, 1994), 120, and Stephen Burton, "Particularism, Discretion, and the Rule of Law," ibid., 178. See also the essays on judges' interpretive strategies by Jack Knight and James Johnson, "Public Choice and the Rule of Law: Rational Choice Theories of Statutory Interpretation," ibid., 244, and William Eskridge and John Ferejohn, "Politics, Interpretation, and the Rule of Law," ibid., 265.

29. See Jeremy Waldron, "The Concept and the Rule of Law," Georgia Law Review 43 (2008): 1.

30. See Martin Shapiro, Courts, A Comparative and Political Analysis (Chicago: University of Chicago Press, 1981), 1-2, and Fuller, "The Forms and Limits of Adjudication," passim.

31. H. L. A. Hart, The Concept of Law, 2nd ed. (Oxford: Clarendon Press, 1994), 96.

32. Hart acknowledges that, of course, secondary rules will have to 
define processes for these institutions (ibid., 97). But he seems to think that this can vary from society to society and that nothing in the concept of law constrains that definition.

33. Joseph Raz, Practical Reason and Norms, new ed. (Oxford: Oxford University Press, 1999), 134-37.

34. Ibid., 132-33.

35. Ibid., 136.

36. Ibid.

37. Raz, "The Rule of Law and Its Virtue," 217.

38. See, e.g., Jamil Anderlini, "Rewards and Risks of Chinese Legal Career," Financial Times, July 24, 2008, where a dissident Chinese lawyer, commenting on abuses of the "court" system in China, observes: "Actually, there is no real legal system in the western sense in China."

39. See Waldron, "The Concept and the Rule of Law," and see also Nigel Simmonds, Law as a Moral Idea (Oxford: Oxford University Press, 2008).

40. Raz, "The Rule of Law and Its Virtue," 224.

41. Fuller, The Morality of Law, esp. chapter 2.

42. See, e.g., H.L.A. Hart, "Book Review of Lon L. Fuller, The Morality of Law," Harvard Law Review 78 (1965): 1281, at 1284. For a characterization of Hart's bewilderment as disingenuous, see Jeremy Waldron, "Positivism and Legality: Hart's Equivocal Response to Fuller," NYU Law Review 83 (2008): 1135, esp. 1154-56.

43. Fuller, "Positivism and Fidelity to Law," 636-37.

44. Fuller, Morality of Law, 162.

45. Shapiro, Courts, 1-2.

46. Fuller, "The Forms and Limits of Adjudication," 366-67.

47. See, e.g., Johan Steyn, "Guantanamo Bay: The Legal Black Hole," Twenty-Seventh F. A. Mann Lecture, November 25, 2003, http://www .statewatch.org/news/2003/nov/guantanamo.pdf.

48. It is also worth noting that the demand for a clear rule to apply to and to regulate the detention is not only a demand for something that the potential detainees can use ex ante to guide their conduct-as though terrorists most wanted to know (and guide their action by) what they were forbidden to do! The demand for the formal aspects of the Rule of Law is often just a way of getting to the procedural aspects of the Rule of Law, which is what the detainees really care about.

49. See Dicey's "Introduction" to the 8th edition of Introduction to the Study of the Law of the Constitution, lv-lvii.

50. Ibid., lvii.

51. Fuller, The Morality of Law, 39 and 81-91.

52. Robert Barro, "Democracy and the Rule of Law," in Governing for Prosperity, ed. B. Bueno de Mesquita and H. Root (New Haven: Yale 
University Press, 2000). See also R. D. Cooter, "The Rule of State Law versus the Rule of Law State: Economic Analysis of the Legal Foundations of Development," in The Law and Economics of Development, ed. E. Buscaglia, W. Ratliff, and R. Cooter (Greenwich, CT: JAI Press, 1997), 101.

53. For examples, see the World Bank ideal of Rule of Law as described by Frank Upham, "Mythmaking in the Rule of Law Orthodoxy," http:// www.carnegieendowment.org/files/wp30.pdf. See also the discussion in Waldron, "Legislation and the Rule of Law," $118 \mathrm{ff}$.

54. Waldron, "Legislation and the Rule of Law," passim.

55. See also the discussion in Jeremy Waldron, "Transcendental Nonsense and System in the Law," Columbia Law Review 100 (2000): 16, 30-40.

56. The legal philosopher who has done the most to develop this theme is, of course, Ronald Dworkin, particularly in Law's Empire (Cambridge, MA: Harvard University Press, 1986).

57. See the discussion of the relation between civil disobedience and disputes about which laws are valid in Ronald Dworkin, Taking Rights Seriously (Cambridge, MA: Harvard University Press, 1977), 184-205. I have discussed this argumentative aspect of Dworkin's conception of the Rule of Law in Jeremy Waldron, "The Rule of Law as a Theater of Debate," Dworkin and his Critics, ed. Justine Burley (Oxford: Blackwell, 2004), 319.

58. See Richard Fallon, "The Rule of Law as a Concept in Constitutional Discourse," Columbia Law Review 97 (1997): 1, 6.

59. See, e.g., Hayek, The Constitution of Liberty, 152-57.

60. Raz, "The Rule of Law and Its Virtue, 214: "This is the basic intuition from which the doctrine of the rule of law derives: the law must be capable of guiding the behaviour of its subjects."

61. See the discussion in Jeremy Waldron, "Is the Rule of Law an Essentially Contested Concept (in Florida)?" Law and Philosophy 21 (2002): 137.

62. See also T. Carothers, "The Rule of Law Revival," Foreign Affairs 77 (1998): 95, and Jeffrey Kahn, "The Search for the Rule of Law in Russia," Georgetown Journal of International Law 37 (2006): 353, 359-61.

63. See, especially, Hayek, The Constitution of Liberty, 153 and 156-57.

64. See also James R. Maxeiner, "Legal Indeterminacy Made in America: U.S. Legal Methods and the Rule of Law," Valparaiso University Law Review 41 (2006): 517, and Antonin Scalia, "The Rule of Law as a Law of Rules," University of Chicago Law Review 56 (1989): 1175.

65. Neil MacCormick, Rhetoric and the Rule of Law: A Theory of Legal Reasoning (Oxford: Oxford University Press, 2005), 14-15 and 26-28. I am greatly indebted to MacCormick's account.

66. Hart, The Concept of Law, 124-36.

67. Ibid., 135-36.

68. See, e.g., Hayek, The Constitution of Liberty, 148-61. 
69. There is a fine account of this in MacCormick, Rhetoric and the Rule of Law, 12-31.

70. Alexis de Tocqueville, Democracy in America (New York: Knopf, 1994), $1: 280$.

71. For the contrast between strong and weak judicial review, see Jeremy Waldron, "The Core of the Case against Judicial Review," Yale Law Journal 115 (2006): 1346.

72. Ronald Dworkin, "Political Judges and the Rule of Law," in his collection A Matter of Principle (Cambridge, MA: Harvard University Press, 1985), 9.

73. Hayek, Constitution of Liberty, 157. This line of thought is even more pronounced in Hayek's later work; see Hayek, Rules and Order, $72 \mathrm{ff}$.

74. See, e.g., Carl Schmitt, The Crisis of Parliamentary Democracy (Cambridge, MA: MIT Press, 1988).

75. The papers that I have found most helpful include James Crawford, "International Law and the Rule of Law," Adelaide Law Review 24 (2003): 3, and Mattias Kumm, "International Law in National Courts: The International Rule of Law and the Limits of the Internationalist Model," Virginia Journal of International Law 44 (2003): 19.

76. See Simon Chesterman, The UN Security Council and the Rule of Law: The Role of the Security Council in Strengthening a Rules-Based International System (Final Report and Recommendations from the Austrian Initiative, 20042008), also published by the Institute for International Law and Justice, New York University School of Law, http://ssrn.com/abstract=1279849.

77. See Jeremy Waldron, “The Rule of International Law," Harvard Journal of Law and Public Policy 30 (2006): 15, and "Are Sovereigns Entitled to the Benefit of the International Rule of Law?” New York University School of Law, Public Law and Legal Theory Research Paper Series, Working Paper no. 09-01 (2009), http://ssrn.com/abstract=1323383. 